\title{
Vibrio sp. causing Porites ulcerative white spot disease
}

\author{
Mark D. M. Arboleda ${ }^{1, *}$, Wolfgang T. Reichardt ${ }^{2}$ \\ ${ }^{1}$ Division of Biological Sciences, University of the Philippines, Miag-ao, Iloilo 5023, Philippines \\ ${ }^{2}$ Marine Science Institute, University of the Philippines, Diliman, Quezon City, Philippines
}

\begin{abstract}
The causative agent of the Indo-Pacific coral disease, Porites ulcerative white spot syndrome (PUWS), that affects Porites spp. and a few other coral genera has so far remained unidentified. Inoculation of thiosulphate citrate bile sucrose (TCBS) agar with tissue material from Porites cylindrica infected with white spot produced colonies of approximately $3 \mathrm{~mm}$ diameter consisting of Gram-negative, motile, non-sucrose-fermenting, slightly curved rods with a minimum $\mathrm{NaCl}$ requirement of $0.3 \%$. Three of these putative Vibrio sp. isolates were used for infection trials that included different stages of cell growth. Four modes of inoculation and 3 stages of bacterial cell growth were considered for testing Koch's postulates. Stationary phase cells proved more consistently infectious than did exponentially growing or starved cells using a 1-step immersion technique at cell concentrations of $10^{4}$ cells ml-1 . A 1-step immersion technique proved more reliable in producing signs of white spot than did other techniques, such as injection, smearing and 2-step immersion of the inoculum. At inoculum densities $>10^{4} \mathrm{cells} \mathrm{ml}^{-1}$ further signs of disease, such as tissue degradation and bleaching, also became evident. At elevated temperatures $\left(>29^{\circ} \mathrm{C}\right)$ bleaching remained absent for at least $2 \mathrm{mo}$ from non-inoculated corals serving as controls, but was observed in artificially infected coral fragments. Of the 9 seawater aquaria containing healthy specimens of $P$. cylindrica, 6 showed signs of white spot 15 d after infection with an isolate tentatively identified as Vibrio sp. Based on $99 \%$ similarity of its 16S rRNA gene sequence and selected phenotypical features, this isolate revealed a close relationship to $V$. natriegens and $V$. parahaemolyticus.
\end{abstract}

KEY WORDS: Indopacific coral disease $\cdot$ Porites $\cdot$ Causative agent $\cdot$ Vibrio

\section{INTRODUCTION}

Coral diseases have become an increasing threat to coral reefs (Harvell et al. 1999). In the Caribbean Sea, coral diseases, such as white pox, were implicated in the loss of more than $70 \%$ of Acropora palmata coral cover (Patterson et al. 2002). In the Indo-Pacific region, coral diseases, such as bleaching, black band, coral tumors (skeletal anomalies), tissue necrosis, pink syndrome and white syndromes (including Porites ulcerative white spot syndrome, PUWS), are becoming widespread (Kushmaro et al. 1998, Ben-Haim et al. 2002, Raymundo et al. 2003, 2005). PUWS affects Porites spp., Goniastrea minuta, Echinopora lamellosa, Heliopora coerulea, Favia stelligera, Favia sp., Montipora grisea, M. malampaya, M. turtlensis, M. digitata, $M$. vietnamensis and $M$. turgescens coral species in the
Philippines (Raymundo et al. 2005, Kaczmarsky 2006). On Bolinao reefs, PUWS showed a prevalence of 2 to $12 \%$, while it remained unclear whether this disease had a significant effect on the coral reef structure (Raymundo et al. 2005). This disease forms characteristic small white lesions ( 3 to $5 \mathrm{~mm}$ ), and while the corals frequently recover, the disease can also progress to cause tissue necrosis and death of the polyps (Raymundo et al. 2003). Healthy corals have been infected by establishing direct contact for $7 \mathrm{~d}$ between healthy and diseased specimens (Raymundo et al. 2003). Yet, the causative agent of this disease remains unknown.

To date, causative agents of 8 coral diseases have been identified. Four of the causative agents belong to the bacterial genus Vibrio, namely V. shiloi, V. charchariae, V. alginolyticus and $V$. coralliilyticus. These bacteria are pathogens of Oculina patagonica, Acrop- 
ora spp., Montastrea spp. and Pocillopora damicornis (Rosenberg et al. 2007). Vibrio species are widespread copiotropic constituents of mesophilic microbial communities that favor organic pollution from shellfish and fish cultivation in coastal marine environments (Colwell et al. 1977, Colwell 1996, Reichardt et al. 2007). This group also harbors the causative agents of an extremely wide range of diseases of commercial marine fishes and shellfish (Bruno et al. 1998, Robertson et al. 1998, Lacoste et al. 2001). At year-round surface water temperatures between 27 and $33^{\circ} \mathrm{C}$ coral reefs in the vicinity of intensive milkfish Chanos chanos mariculture at Cape Bolinao (Lingayen Gulf, Philippines) are particularly exposed to high densities of different populations of Vibrio spp. (W. T. Reichardt et al. unpubl. data). Thus, a highly selective enrichment medium for marine vibrios, such as thiosulphate citrate bile sucrose (TCBS) agar (Bolinches et al.1988), was considered as first choice for isolating test strains from white spots of diseased Porites cylindrica to test Koch's postulates (Rosenberg 2004). Since extracellular proteases are the only known virulence factor of coral pathogens (Kushmaro et al.1998, Rosenberg 2004), isolates from TCBS agar were also screened for this enzyme activity.

Several techniques of inoculation have been designed for testing Koch's postulates to identify causative agents of coral diseases (Kushmaro et al. 1998, Ben-Haim et al. 2002, Patterson et al. 2002, Smith and Weil 2004). Our infection trials with proteolytic isolates of putative vibrios took into account that Vibrio spp. undergo starvation survival, and that their proteases are induced only in survival stages (Roszak \& Colwell 1987, Albertson et al. 1990, Morita 1999, Oliver 2005). Another factor considered in our experiment was the density of cells applied in the inoculum. $V$. coralliilyticus can cause coral death already at cell densities as low as $10^{4}$ cells ml ${ }^{-1}$ (Ben-Haim \& Rosenberg 2002).

\section{MATERIALS AND METHODS}

Collection of corals. Bolinao Bay area (Lingayen Gulf, Luzon, Philippines) is characterized by approximately $50 \mathrm{~km}^{2}$ of a fringing reef system. Water temperatures peak from 32 to $35^{\circ} \mathrm{C}$ during summer months (April and May), and decline to 26 to $28^{\circ} \mathrm{C}$ during the northeast monsoon period in January and February; salinities fluctuated between 30 and 35 (M. D. M. Arboleda unpubl. data). White syndromes including PUWS are the most predominant coral diseases observed year-round (Raymundo et al. 2005). Samples of Porites cylindrica showing PUWS signs were first collected from reef sites at Malilnep $\left(15^{\circ} 25^{\prime} 19^{\prime \prime} \mathrm{N}\right.$, $\left.119^{\circ} 57^{\prime} 20^{\prime \prime} \mathrm{E}\right)$ and Lucero (15 21' 19" N, $119^{\circ} 59^{\prime} 20^{\prime \prime} \mathrm{E}$ ) between 4 September 2005 and 18 February 2009. For infection experiments, samples comprising 750 healthy P. cylindrica coral fragments (nubbins) were collected between 28 June 2007 and 16 March 2009. Nubbins were mounted directly onto ceramic tiles with marine epoxy or inserted into PVC tubes (13 mm diameter, $3 \mathrm{~cm}$ high), which were then glued onto ceramic tiles with marine epoxy (Dizon et al. 2008). Nubbins of healthy $P$. cylindrica were maintained and prepared for inoculation trials in aquaria fed with sand-filtered seawater in a roofed open-air hatchery. Water used in the preliminary experiments was constantly pumped from its source $200 \mathrm{~m}$ directly in front of the outdoor hatchery after passing through a sand filter. Water used for the final infection trial using 1-step immersion was further purified by a series of compact filters (50, 12 and $10 \mu \mathrm{m}$ ) and UV sterilization. Water losses due to evaporation were compensated for by daily replenishment from a source of distilled water. Unless controlled by immersion heaters, temperatures were monitored daily at 11:00 and 23:00 $\mathrm{h}$. To avoid contamination by wind-blown particles, the $20 \times 30 \times 40 \mathrm{~cm}$-sized aquaria were protected with plexiglass covers leaving a $1 \mathrm{~cm}$ space for gas exchange. Following an equilibration period of $2 \mathrm{wk}$, the appearance of disease signs was monitored at daily intervals. This was a precautionary step to detect and exclude from the trials any coral specimens that would develop signs of PUWS during the holding period of 2 wks before the test strains were inoculated.

Isolation of test strains. Tissue material from white spots of 5 randomly selected diseased Porites cylindrica specimens from Malilnep reef site was collected with sterile syringes. Serial dilutions of this material in sterile seawater were plated onto TCBS agar (HiMedia). The most abundant colony types of putative vibrios were isolated and subjected to several alternating transfers on TCBS agar and marine agar (HiMedia), before being maintained on marine agar slants. Twenty of these isolates were screened for ectoprotease activity in nutrient broth cultures based on dye release from $20 \mathrm{mg}$ amounts of hide powder azure (Sigma) serving as enzyme substrate (Rinderknecht et al. 1968, Reichardt 1988). Three of a total of 10 protease-positive isolates were selected for infection trials.

Infection trials. Infection trials were initiated with mounted coral fragments that were placed in glass aquaria with UV-sterilized and filtered seawater. The set-up was placed in a roofed hatchery. To ascertain that the coral fragments were disease-free, the mounted coral fragments underwent an equilibration (quarantine) period of $2 \mathrm{wk}$. Preliminary trials involving 3 different stages of cell growth and 4 different modes of inoculation were conducted to determine the most reliable infection technique. These trials were 
performed in $50 \mathrm{l}$ aerated aquaria $(60 \times 30 \times 40 \mathrm{~cm})$, each containing 6 coral nubbins. Final experiments were conducted with 9 replications, each containing 3 coral nubbins. Suspensions of $10^{4}$ cells $\mathrm{ml}^{-1}$ stationary phase Vibrio sp. T5 served as the inoculum using a 1-step immersion technique. Two controls containing 9 replicates each were inoculated as follows: (1) with suspensions of $10^{4} \mathrm{ml}^{-1}$ heat-killed stationary phase Vibrio T5, or (2) with $100 \mathrm{ml}$ sterile seawater (SSW). Water levels in the aquaria were adjusted periodically with sterile distilled water to maintain salinity.

Preparation of inocula. Three proteolytic isolates were tested at different growth stages that involved exponentially growing, stationary and starved cells. Volumes of $800 \mathrm{ml}$ of batch cultures that had been agitated $(150 \mathrm{rpm})$ in marine broth (HiMedia) were harvested after $1 \mathrm{~d}$ of exponential growth at $30^{\circ} \mathrm{C}$ by centrifugation in $50 \mathrm{ml}$ Falcon tubes at $2900 \times g$ (Eppendorf A-4-62 swing bucket) for $10 \mathrm{~min}$. Pellets were resuspended in $10 \mathrm{ml}$ of SSW, centrifuged and transferred into $10 \mathrm{ml}$ (final volume) of SSW. Estimates of cell density were based on microscopic counts of cells stained with DAPI (Porter \& Feig 1980). After 4 d, stationary phase cells were obtained by centrifugation of batch cultures, which were then resuspended in SSW as stated above (Oliver et al. 1991). Starved cell suspensions were prepared from washed cells obtained by repeated centrifugation of batch cultures harvested after $1 \mathrm{~d}$ of exponential growth, resuspension in SSW and incubation on a shaker (150 rpm) for $4 \mathrm{~d}$ at $30^{\circ} \mathrm{C}$ (Nystrom et al. 1992).

Modes of inoculation. For direct injection, concentrated cell suspensions $\left(10^{9}\right.$ cells $\left.\mathrm{ml}^{-1}\right)$ were injected into corallites by means of a 26 gauge hypodermic needle. The nubbins were then submerged in a small jar containing seawater and transferred to 50 l, aerated, flow-through aquaria. Nubbins injected with SSW before aquaria transfer served as untreated controls.

For 2-step immersion, $5 \mathrm{~cm}$ coral fragments were immersed overnight in aerated $300 \mathrm{ml}$ jars with SSW containing $10^{9}$ cells $\mathrm{ml}^{-1}$ of the inoculum and then transferred to aerated $50 \mathrm{l}$ flow-through aquaria. Immersion in SSW before aquaria transfer served as controls.

Inoculation by smearing was a modified procedure of Ben-Haim et al. (2003). Coral nubbins were rinsed in SSW, drip-dried and smeared with $10^{9}$ cells ml-1 before being transferred to flow-through tanks.

For 1-step immersion (Ben-Haim et al. 2003) coral nubbins were placed in sea water aquaria containing the inocula at final cell densities of $10^{9}, 10^{6}, 10^{4}$ and $10^{3}$ cells $\mathrm{ml}^{-1}$. Nubbins in SSW served as untreated controls.

Taxonomic characterization of isolates. Isolates eliciting signs of PUWS underwent phenotypic and genotypic screening. Phenotypic identification involved key features of vibrios (Farmer \& Janda 2005,
Noguerola \& Blanch 2008) and included the following criteria: growth on TCBS agar, growth in nutrient broth containing $0,0.1,0.2,0.3,0.5,1.0,3.0,6.0,8.0,10.0$ and $12.0 \% \mathrm{NaCl}$, swarming on marine agar, bioluminescence on marine agar, growth at $40^{\circ} \mathrm{C}$, motility, Gramstaining, cytochrome oxidase, arginine dehydrolase, ornithine and lysine decarboxylase activity, indole production, gelatinase production, acetoin production (Voges-Proskauer test), nitrate reduction, indole production, acid from D-glucose, gas from D-glucose, utilization of cellobiose, and D-gluconic acid. Further tests were provided by the Biolog GN2 system (Biolog) at a final $\mathrm{NaCl}$ concentration of $3.0 \%$. Bacterial growth on marine agar was suspended in GN/GP inoculating fluid (Biolog) and adjusted to absorbance readings of 0.10 at $590 \mathrm{~nm}$. A bacterial suspension of $150 \mu \mathrm{l}$ was pipetted into each well of the GN2 microplates (Biolog). Microplates were incubated at $30^{\circ} \mathrm{C}$ for 4 to $24 \mathrm{~h}$ depending on the rate of purple color formation. Color changes were recorded either visually or with a plate reader (BioRad) at $520 \mathrm{~nm}$. Flagella of isolate T5 were examined in negatively stained samples of a growing culture suspension stained with $1 \%$ uranyl acetate (Harris 2007).

For genotypic analyses, DNA was extracted from exponentially growing cultures (Sambrook et al. 1989). Isolates were grown overnight at $30^{\circ} \mathrm{C}$ in Luria-Bertani (LB) medium amended with $3 \% \mathrm{NaCl}$ and harvested by centrifugation $10000 \times g$ for $1 \mathrm{~min}$. Pellets were resuspended in lysis buffer and centrifuged again. The supernatant was transferred to a fresh $1.5 \mathrm{ml}$ tube with $300 \mu \mathrm{l}$ of phenol:chloroform (24:1) and mixed to remove residual proteins. The tube was centrifuged and the upper aqueous layer was transferred to a fresh $1.5 \mathrm{ml}$ tube. The DNA in the aqueous phase was precipitated by centrifugation in twice its volume of $70 \%$ ice-cold ethanol. The pelleted DNA was then re-suspended in $50 \mu \mathrm{l}$ Tris-ethylenediaminetetraacetic acid (TE) buffer and stored at $-21^{\circ} \mathrm{C}$. From the re-suspended DNA, 16S rDNA was amplified by PCR, and the reaction products were purified and sequenced. The 16S rDNA amplification process was done in a $50 \mu$ reaction mixture consisting of $5 \mu$ l of $10 \times$ PCR buffer, $5 \mu$ l of $2.5 \mathrm{mM}$ total dNTPs mixture, $1 \mathrm{mM}$ of each primer, $1 \mu \mathrm{g}$ template DNA and $2.5 \mathrm{U}$ of Taq DNA polymerase (Invitrogen). The primers used were general prokaryotic $16 \mathrm{~S}$ rDNA primers: forward 5'-AGA GTT TGA TYM TGG CTC AG and reverse 5'-ACC TTG TTA CGA CTT (Y = C/T, M = A/C) (Invitrogen). Amplification conditions for the PCR included denaturation at $94^{\circ} \mathrm{C}$ for $5 \mathrm{~min}$, followed by 30 cycles of $94^{\circ} \mathrm{C}$ for $1 \mathrm{~min}, 55^{\circ} \mathrm{C}$ for $1 \mathrm{~min}$ and $72^{\circ} \mathrm{C}$ for $45 \mathrm{~s}$. The final extension step was at $72^{\circ} \mathrm{C}$ for $5 \mathrm{~min}$. Reaction products were purified and then sent to Macrogen (Korea) for sequencing. The resulting $1.5 \mathrm{kbp}$ fragment of the 
putative Vibrio 16S rDNA sequence was compared with homologous published sequences.

Sequence similarity to published $16 \mathrm{~S}$ ribosomal RNA (rRNA) was done by BLAST (Altschul et al. 1990). Calculations of similarity values were based on neighborjoining methods (Kita-Tsukamoto et al. 1993) with Bioedit (Hall 1999).

Re-isolations. Material from white spots of field specimens of Porites cylindrica that had been infected with the putative causative agent triggering PUWS were collected with a syringe and plated onto TCBS agar plates. A total of 10 colonies showing similar characteristics as the putative causative agent were isolated for further identification involving selected phenotypic tests and 16S rRNA gene sequencing.

Statistical methods. One-way ANOVA from Statistica v. 7 (StatSoft) was used to determine whether significant differences existed among infection trial treatments of Porites cylindrica.

\section{RESULTS}

\section{Choice of isolates for infection trials}

During the summer of 2006, Porites cylindrica specimens showing signs of PUWS were collected from a reef site at Malilnep channel and screened for the presence of putative Vibrionaceae. More than $80 \%$ of the colonies growing on TCBS agar were non-fermenters of sucrose. Of the sucrose non-fermenters (isolates T2, T3 and T5) 3 out of 20 showed high ectoprotease activity in an arbitrary and semi-quantitative test. These isolates came from the same reef site, but from different PUWS affected $P$. cylindrica specimens. TCBS agar colonies resembling the sucrose nonfermenting isolate T5 were found in all of 10 field samples from white spots of PUWS infected P. cylindrica. This type of isolate was not found on the surface of 10 healthy field samples of $P$. cylindrica serving as controls.

\section{Response patterns in preliminary infection trials}

Isolates T2, T3 and T5 were chosen for preliminary infection trials by using cell suspensions of different growth status (cell types) as inoculum and applying different modes of inoculation. Depending on these conditions and on the titer of the cell suspension used as inoculum, white spots, tissue degradation (lysis of the coral tissue) and bleaching were observed (Table 1). Signs of PUWS were only observed in the 1step immersion trials treated with T5 (stationary cells at $10^{6}$ to $10^{3}$ cells $\mathrm{ml}^{-1}$; exponentially growing and starved cells at $10^{4}$ cells $\mathrm{ml}^{-1}$ ) and T2 (starved cells at $10^{4}$ cells ml ${ }^{-1}$ ) (Fig. 1). The highest percent of nubbins in an aquarium showing signs of PUWS was observed in a 1-step immersion trial treated with T5 stationary cells at $10^{4}$ cells $\mathrm{ml}^{-1}(83 \%)$. No PUWS signs were observed in the injection, 2-step immersion or smearing methods that used more concentrated inocula of any isolate. Tissue degradation (Fig. 1) occurred after

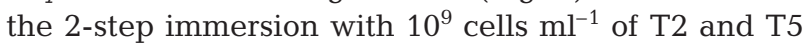
(exponentially growing and starved cells). Tissue degradation was further observed after 1-step immersion at titers of $10^{6}$ and $10^{9}$ cells $\mathrm{ml}^{-1}$ with isolates T2 and T5 as exponentially growing cells (100\%), at $10^{4}$ cells $\mathrm{ml}^{-1}$ with isolates T5, as exponentially growing $(100 \%)$, and at $10^{4}$ cells $\mathrm{ml}^{-1}$ with stationary phase cells of isolate T5 (17\%). Tissue degradation was also observed in corals treated by smearing with exponentially growing and stationary phase cells of isolate T3. Bleaching occurred only in Porites cylindrica nubbins that had been treated by smearing with isolate T5. $P$. cylindrica nubbins that were not inoculated with any bacterial isolate (control treatment with sterile seawater) did not produce any signs of PUWS, and did not show either necrosis or bleaching in any of the infection modes applied.

Within an experimental temperature range varying from 24.5 to $34^{\circ} \mathrm{C}$, all 6 corals remained healthy and pigmented for $10 \mathrm{~d}$ after infection. White spots began to show $15 \mathrm{~d}$ after inoculation at cell densities of $10^{4}$ cells $\mathrm{ml}^{-1}$. Most consistent infection results were obtained with stationary phase cells of isolate Vibrio sp. isolate T5. By Day 25, 5 of the 6 infected corals were bleached. Bleached corals eventually progressed to show tissue degradation after $2 \mathrm{wk}$. Occasionally, signs of bleaching disappeared after the same time period of $2 \mathrm{wk}$. However, an inoculum titer of $10^{6}$ cells $\mathrm{ml}^{-1}$ caused signs of lysis 2 wk after inoculation in 3 of 6 replicates.

A titer of $10^{9}$ cells $\mathrm{ml}^{-1}$ resulted in infection of all 6 infected replicate coral nubbins and their death. Tissue degradation (Fig. 1) typically started as patches, usually on the verrucae of the branches, which slowly united and progressed until the entire tissue was degraded, leaving only the bare skeleton. Coral fragments serving as controls that were inoculated with SSW remained healthy and pigmented in all treatments for at least 2 mo (Table 1, Fig. 1).

\section{Final choice of infection trials}

In combination with stationary growth cells serving as inoculum 1-step immersion proved the most effective infection technique. This technique was chosen for improved infection trials with putative Vibrio isolate 


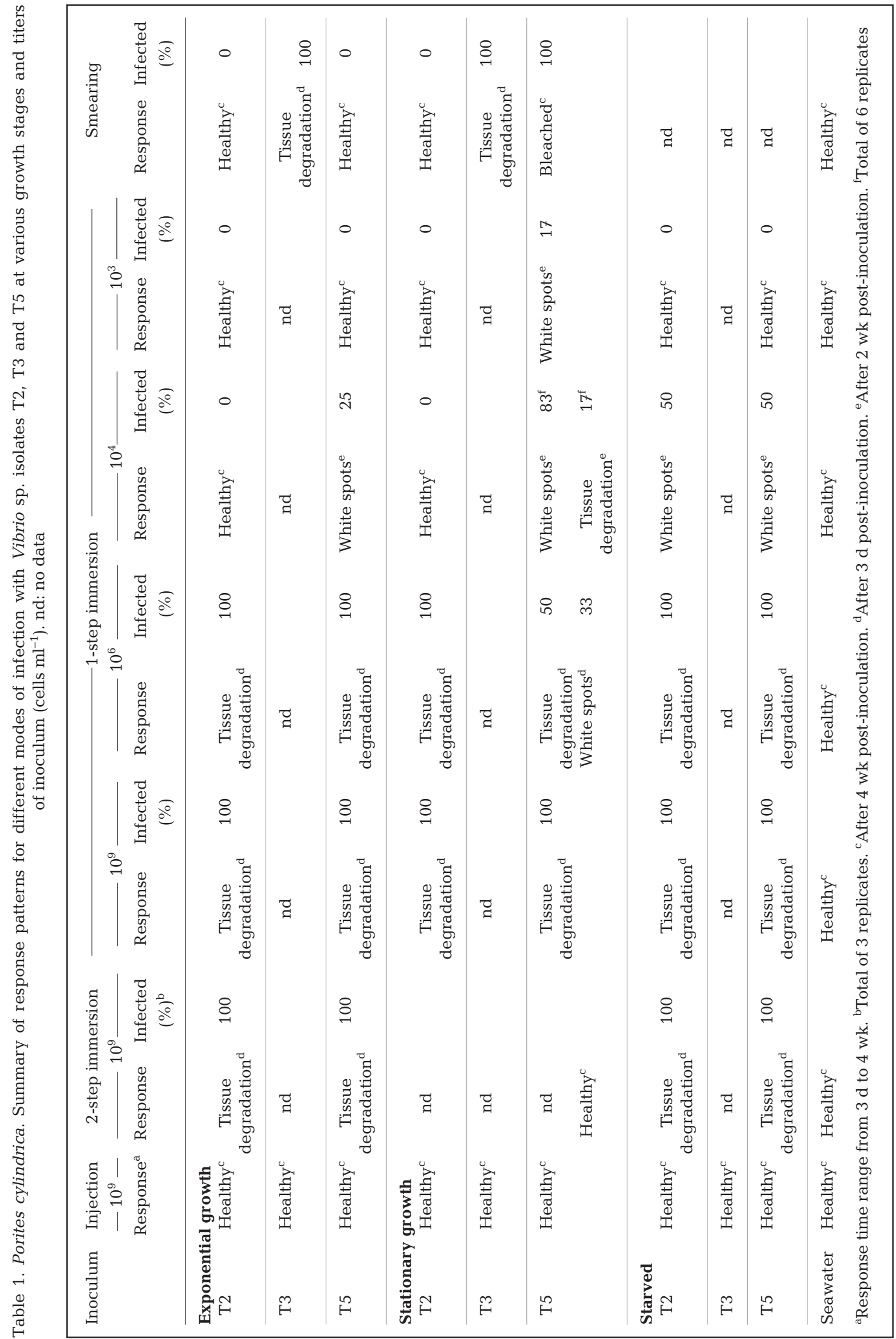




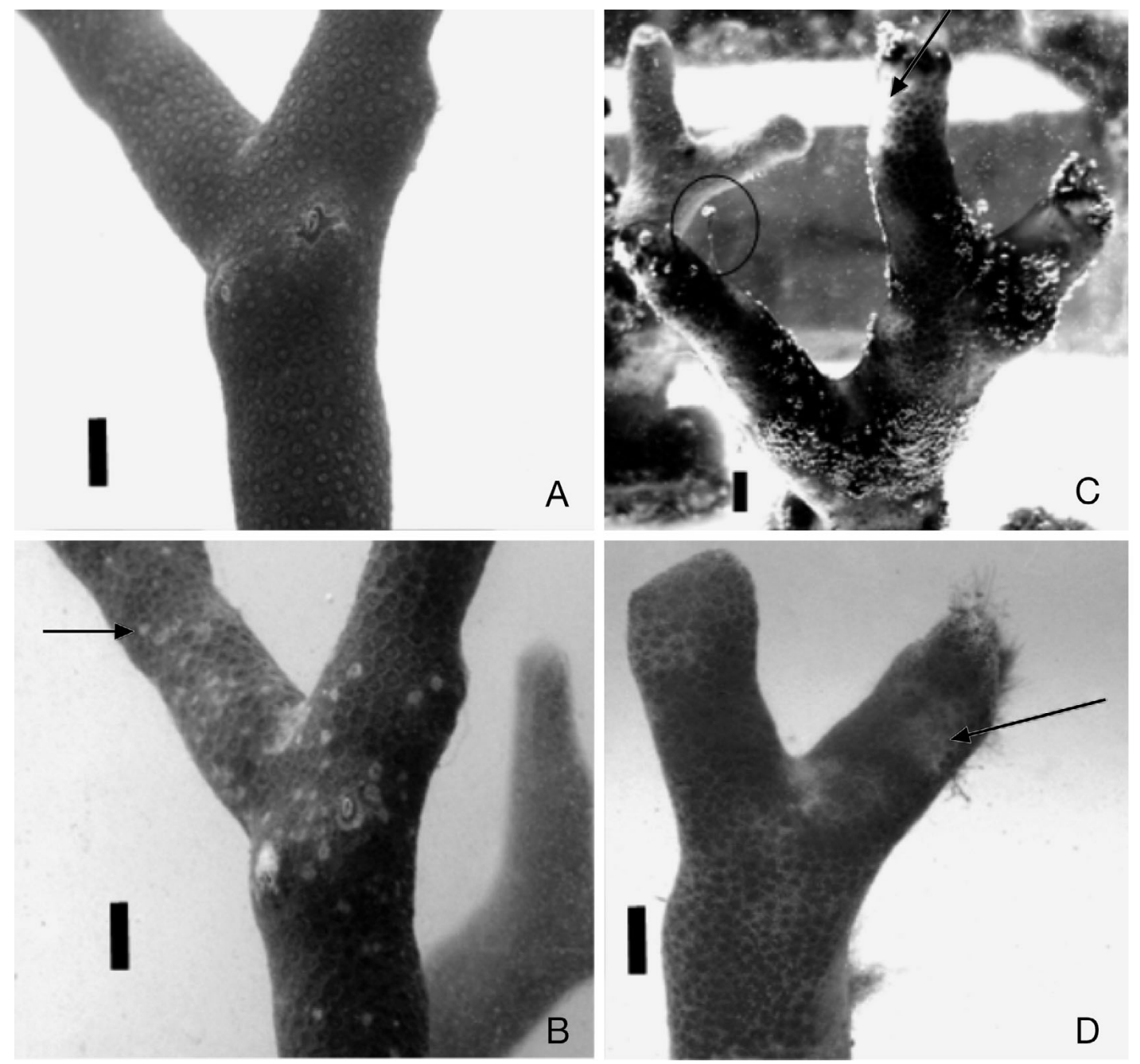

Fig. 1. Porites cylindrica. Infection of coral with isolate Vibrio sp. T5. Images of (A) healthy P. cylindrica, (B) Porites ulcerative white spot syndrome (arrow: ulcer), (C) tissue degradation (arrow: bleached tissue; circle: degraded tissue) and (D) bleaching (arrow) of infected coral. Scale bars $=1 \mathrm{~cm}$

T5 as the most promising test strain. In these trials, replication was completed by keeping all 9 replicates of each treatment in separate aquaria. Trials were run in the middle of the dry season from November 2008 to February 2009 at the following ranges of physicochemical conditions in the aquaria: water temperatures from 25.1 to $30.6^{\circ} \mathrm{C}$, daytime light intensity from 15 to $150 \mu \mathrm{E} \mathrm{mol}{ }^{-1} \mathrm{~cm}^{-2}$, dissolved oxygen from 5.5 to $8.1 \mathrm{mg} \mathrm{l}^{-1}$ and salinity from 33.2 to 35.2 .

At a final density of $10^{4}$ cells $\mathrm{ml}^{-1}$ stationary phase test strain T5 elicited the first signs of PUWS infection (small spots in 1 out of 9 aquaria) on Porites cylindrica nubbins $7 \mathrm{~d}$ after inoculation (Fig. 2). At this time average physical conditions recorded in the aquaria were: $29.0^{\circ} \mathrm{C}, 7.1 \mathrm{mg} \mathrm{l}^{-1}$ dissolved oxygen, salinity of 33.4 and light intensity of $70 \mu \mathrm{E} \mathrm{mol} \mathrm{m}^{-1} \mathrm{~cm}^{-2}$. Ulcerative white spots were observed $16 \mathrm{~d}$ after inoculation in 3 of 9 aquaria at $29.7^{\circ} \mathrm{C}, 7.5 \mathrm{mg} \mathrm{l}^{-1}$ dissolved oxygen, salinity of 34.1 and light intensity of $34 \mu \mathrm{E} \mathrm{mol}{ }^{-1} \mathrm{~cm}^{-2}$ (Fig. 3). The frequency of PUWS infection, $32 \mathrm{~d}$ after inoculation, had risen to 6 out of 9 aquaria at $29.2^{\circ} \mathrm{C}, 6.5 \mathrm{mg} \mathrm{l}^{-1}$ of dissolved oxygen, salinity of 33.1 and light intensity of $10 \mu \mathrm{E} \mathrm{mol} \mathrm{m}^{-1} \mathrm{~cm}^{-2}$. In the aquaria showing infection, 18 infected corals were randomly sampled for the T5 re-isolate.

Treatments with stationary phase isolate T5 were significantly different from both those with heat-killed stationary phase isolate T5 and those serving as uninoculated controls ( $p>0.05)$. In the treatment with heat-killed isolate T5 white spots were observed sporadically and earlier (after $3 \mathrm{~d}$ ) than in the treatment with stationary phase isolate T5, but disappeared again after 1 d. (Fig. 2). White spots appeared after $26 \mathrm{~d}$ in 1 of 9 replicates, but had disappeared again the 


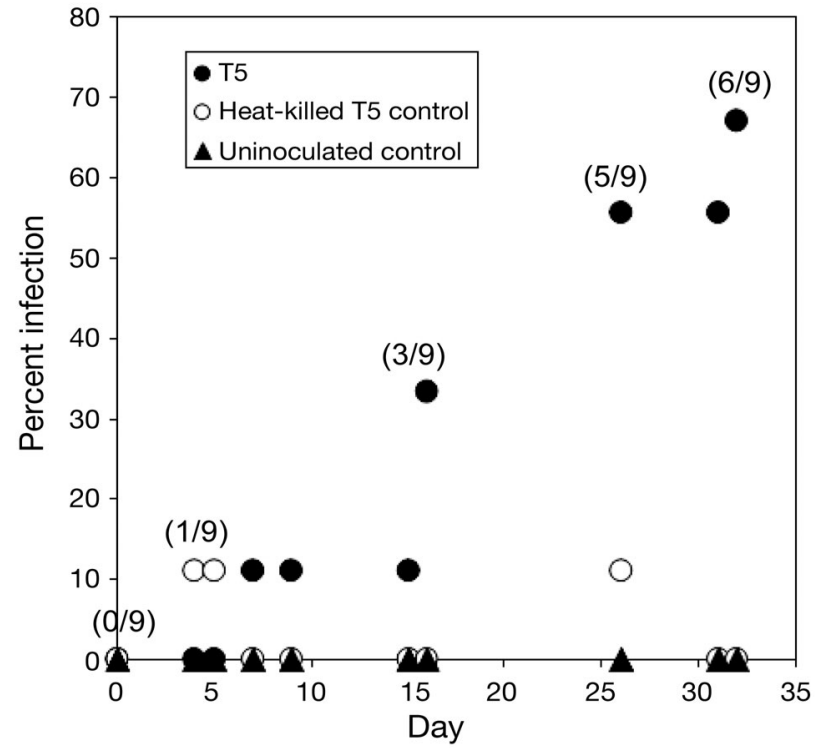

Fig. 2. Porites cylindrica. Time course of percent infections of corals in replicate aquaria $(\mathrm{n}=9)$ with isolate Vibrio $\mathrm{sp}$. T5 using 1-step immersion method. Values in parentheses indicate no. of nubbins infected/total. Diurnal temperature range: 25 to $31^{\circ} \mathrm{C}$

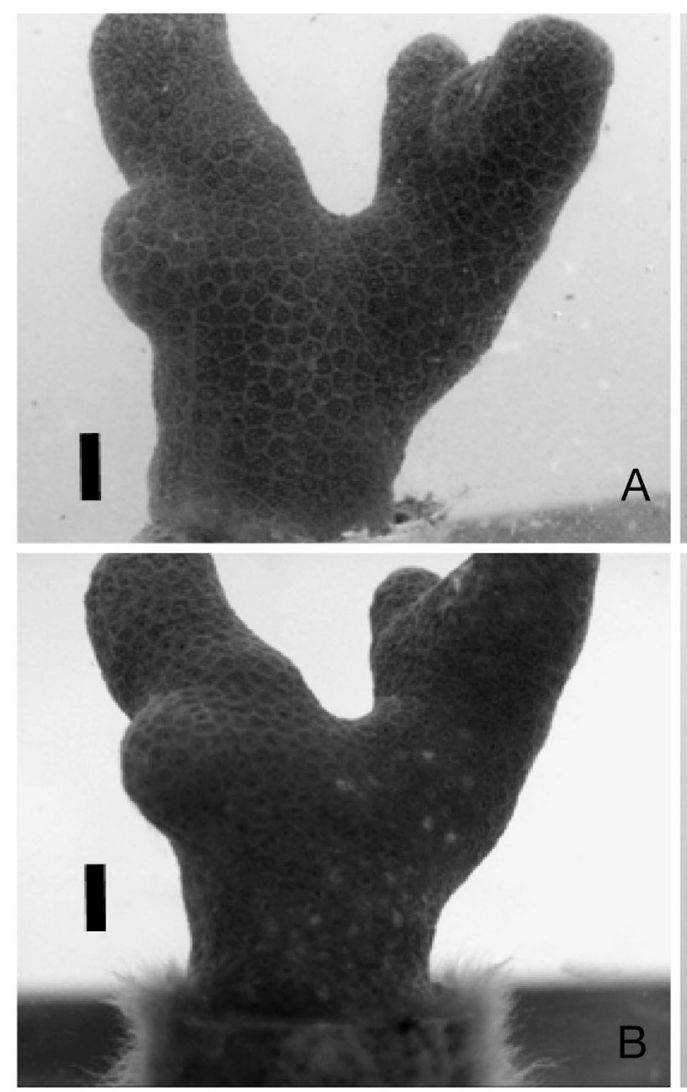

next day. No ulcerative white spots were observed in the uninoculated control receiving only sterile seawater (Fig. 3).

\section{Taxonomic characterization of strains tested}

Isolates T2, T3 and T5 were sucrose non-fermenting, Gram-negative, motile curved rods (1.0 to $1.3 \times 0.7 \mu \mathrm{m})$ with polar flagella forming small $(3 \mathrm{~mm})$ colonies on both TCBS and marine agar. All 3 strains required $\mathrm{NaCl}$ for growth at a concentration in the range of 0.3 to $8 \%$, were cytochrome oxidase positive, fermented glucose, reduced nitrate to nitrite without gas production, lacked arginine dihydrolase and ornithine decarboxylase activities, did not utilize cellobiose or gluconate, and showed negative responses in VogesProskauer tests for acetoin production (using $1 \%$ Baritt medium at $\mathrm{pH}>6.0$ ), but produced indol.

Further phenotypical characterization of strain T5 indicated growth at $40^{\circ} \mathrm{C}$ and utilization of the following BIOLOG substrates: adonitol, myo-inositol, lactose, raffinose, dextrin, Tween 40, Tween 80, N-acetyl-D-

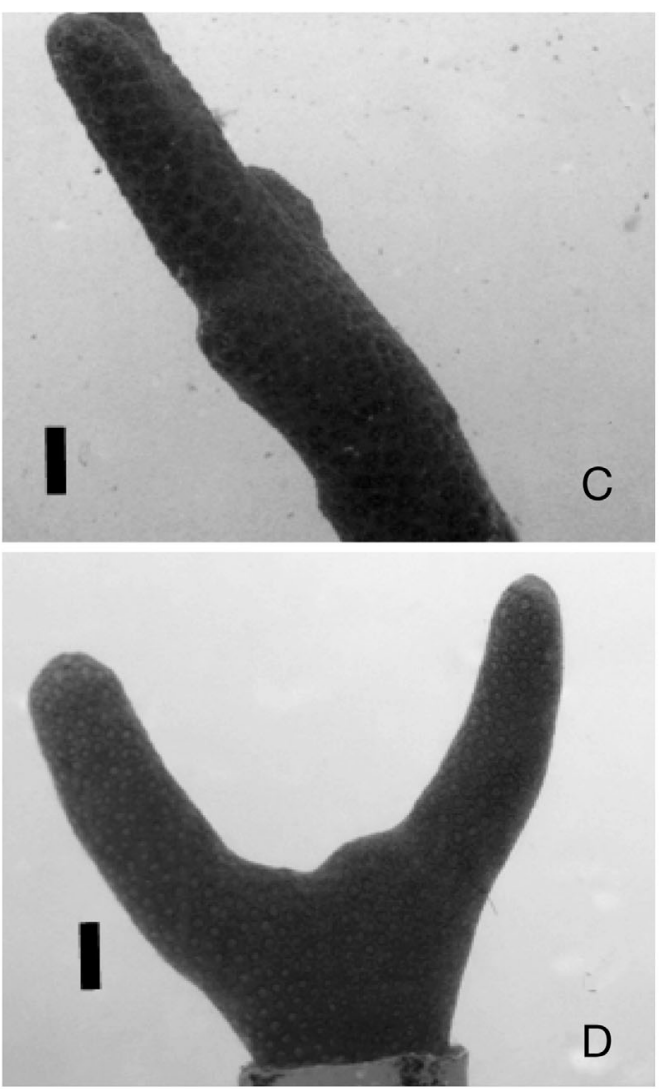

Fig. 3. Porites cylindrica. Infection of corals with isolate Vibrio sp. T5 using 1-step immersion method. Images of (A) healthy P. cylindrica. (B) P. cylindrica $16 \mathrm{~d}$ post-inoculation with stationary phase isolate Vibrio sp. T5, (C) P. cylindrica $16 \mathrm{~d}$ postinoculation with heat-killed stationary phase Vibrio sp. T5, (D) Porites cylindrica 16 d post-inoculation with sterile water (control). 


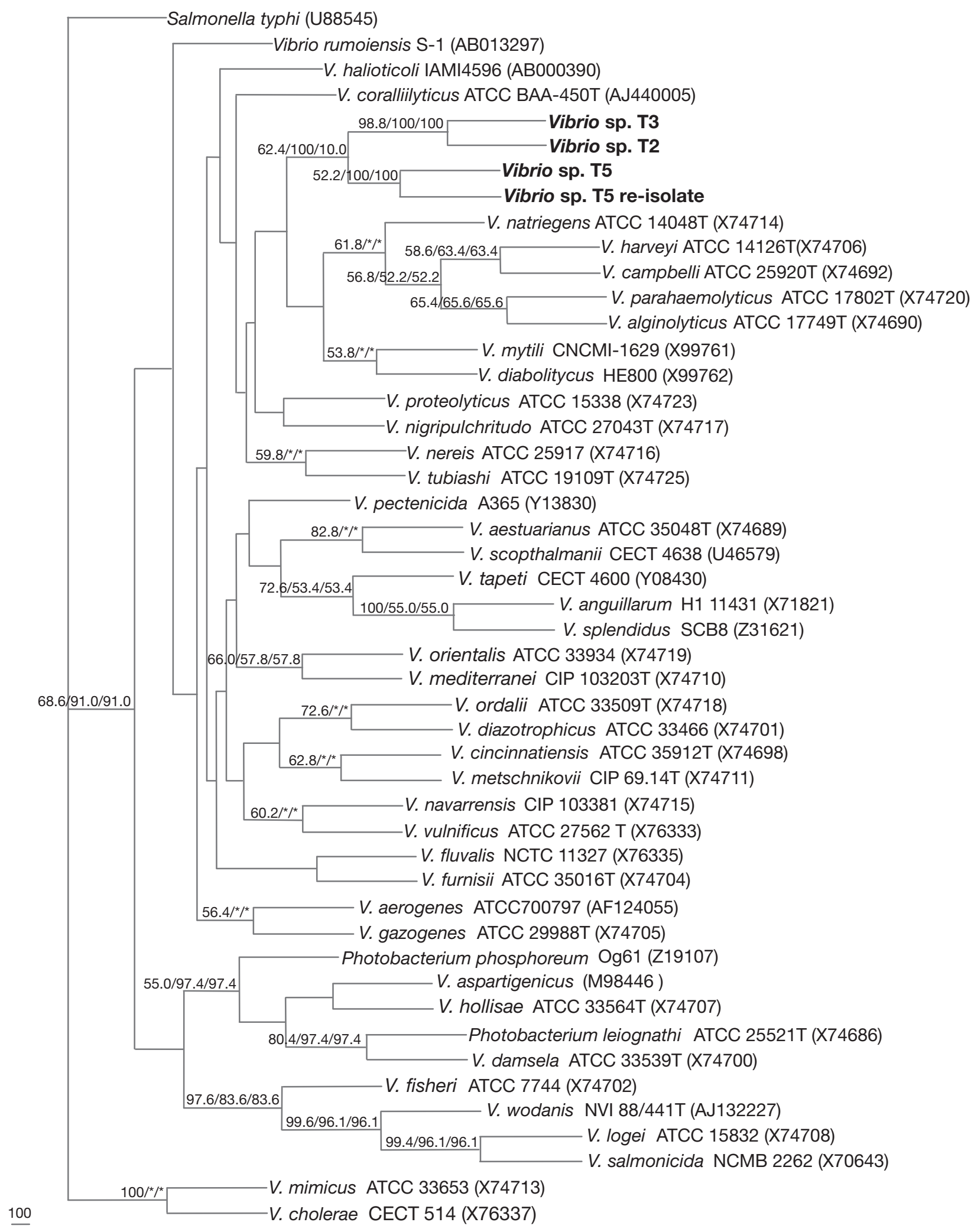

Fig. 4. Phylogenetic tree based on 16S rRNA sequences using neighbor-joining, parsimony and maximum likelihood methods, showing the relationship of Vibrio sp. isolates T5, T2 and T3 (in bold) with Vibrio reference strains and their closest BLAST homologues. Bootstrap percentages ( $\geq 50 \%$ ) after 500 simulations are shown; asterisks $\left({ }^{*}\right)$ indicate $<50 \%$ bootstrap. Sequence accession numbers are given in brackets (Salmonella typhi served as an outgroup). Scale bar $=100 \mathrm{bp}$ 
galactosamine, $\alpha$-D-glucose, lactulose, D-psicose, Lrhamnose, D-sorbitol, turanose, acetic acid, D-glucuronic acid, D-glucosaminic acid, D-glucoronic acid, $\gamma$ hydroxybutyric acid, $\alpha$-keto butyric acid, propionic acid, glucuronomide, L-alanine, L-alanyl glycine, Lasparagine, L-aspartic acid, L-glutamic acid, glycyl-Laspartic acid, glycyl-L-glutamic acid, hydroxyl-L-proline, L-ornithine, L-proline, D-serine, L-threonine, inosine, uridine, thymidine, glycerol, D,L- $\alpha$-glycerol phosphate, $\alpha$-D-glucose-1-phosphate, D-glucose-6phosphate and gelatin. No utilization was noted for the following BIOLOG substrates: D-cellobiose, sucrose, gluconate, $\alpha$-cyclodextrin, glycogen, L-arabinose, Darabitol, i-erythritol, D-fucose, D-galactose, gentobiose, maltose, D-mannitol, D-mannose, D-melibiose, $\beta$ methyl-D-glucoside, D-trehalose, xylitol, pyruvic acid methyl ester, succinic acid mono-methyl ester, cisaconitic acid, citric acid, formic acid, D-galacturonic acid lactose, D-galacturonic acid, $\alpha, \beta$ hydroxybutyric acid, p-hydroxy phenylacetic acid, itaconic acid, $\alpha$-keto glutaric acid, $\alpha$-keto valeric acid, D,L-lactic acid, malonic acid, guinic acid, D-saccharic acid, sebacic acid, succinic acid, L-alaninamide, D-alanine, L-histidine, L-leucine, phenyl alanine, L-pyroglutamic acid, L-serine, D,L- carnitine, $\gamma$-aminobutyric acid, urocanic acid, phenylethylamine, putrescine, 2-aminoethanol,

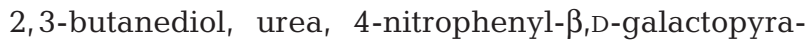
noside and esculin.

Using a nucleotide similarity search (BLAST), the $16 \mathrm{~S}$ rRNA gene sequence of isolate T5 showed 99\% similarity to Vibrio parahaemolyticus AY303956. However, a cladogram based on the sequences of Vibrio type strains and neighbor-joining methods placed isolate T5 in the immediate vicinity of $V$. natriegens X74714, but still in the neighborhood of $V$. parahaemolyticus X74720 (Fig. 4). This cladogram also reflected sequence similarity matrix values of 80.6 and $81.0 \%$ of isolates T2 and T3, respectively, to isolate T5 (Fig. 4).

\section{Re-isolation of causative agent}

Vibrio T5 was re-isolated from ulcerative white spots of artificially infected Porites cylindrica. Similiarity of the sucrose non-fermenting isolate on TCBS to the inoculum strain T5 was close enough to consider it as putative re-isolate. Confirmation of the re-isolation of Vibrio isolate T5 was shown by 16S rRNA gene sequence analysis. The re-isolate was shown to be $97 \%$ similar to the putative causative agent T5. In contrast, TCBS agar isolates from healthy P. cylindrica were dominated by sucrose fermenting colonies. None of the non-fermenting TCBS colonies obtained from the surface of healthy corals matched the putative causative agent, Vibrio T5.

\section{DISCUSSION}

\section{Vibrios in Bolinao Bay waters}

Extremely high densities of various Vibrio populations may be caused by organic matter input from intensive milkfish farming near coral reef sites at prevailing water temperatures around $30^{\circ} \mathrm{C}$ (Reichardt et al. 2007). The majority of known coral disease-causing bacteria are also Vibrio species (Rosenberg et al. 2007). Therefore, screening of Porites white spots on TCBS agar for putative Vibrio spp. was a promising approach to detect the causative agent of PUWS (Bolinches et al. 1988, Ben-Haim \& Rosenberg 2002). In contrast to earlier results obtained in open-water bacterial monitoring with TCBS plate counting, the majority of putative Vibrio spp. from white spots showed no fermentation of sucrose on TCBS agar. This non-fermenting subgroup tends to be more often associated with Vibrio spp. of the intestinal microflora of milkfish and other oxygen-deficient microhabitats in Bolinao Bay (W. T. Reichardt unpubl. data). A recent semi-quantitative comparison of bacterial genetic markers from the fish farming area of Bolinao Bay and nearby coral reefs has already suggested a 'wash-out' of certain bacteria, predominantly Vibrio spp., from the fish cages to the coral reefs (Garren et al. 2008).

\section{Design of infection trials}

Four different infection techniques have so far been applied to identify coral diseases (Kushmaro et al. 1997, Ben-Haim \& Rosenberg 2002, Patterson et al. 2002, Cervino et al. 2004, Smith \& Weil 2004). Infection by injection and smearing involved mechanical stimulation of the corals and could have been negatively affected by coral antibacterial responses (Geffen \& Rosenberg 2005). However, extracts from mechanically stimulated Porites cylindrica nubbins failed to inhibit the growth of test strain Vibrio sp. T5 on TCBS agar (authors' unpubl. data). Infection techniques that were only based on transmission through water (2-step and 1-step immersion) could have improved the conditions for successful infection, if PUWS required similar cell surface interaction and signaling as described for the host-mucus-pathogen system of infections by toxin P-producer $V$. shiloi of the coral Oculina patagonica (Banin et al. 2000). A comparison of all 4 methods revealed that the most consistent signs of PUWS were obtained with 1-step immersion and resulted in the subsequent use of this technique. An effect of ambient diurnal temperature shifts between the measured extremes of 24 and $34^{\circ} \mathrm{C}$ could not be excluded. 
In the upper temperature range, abiotic bleaching effects on corals can occur when temperatures rise above the temperature tolerances of corals (HoeghGuldberg 1999). Since none of the non-inoculated controls in the trials showed bleaching (Table 1), such an effect was discounted. Sporadic bleaching was, however, noted in a few corals that had been infected by smearing. This observation could support the view that bleaching of corals depends on both abiotic and biotic factors (Ben-Haim \& Rosenberg 2002). In an immersion-heater-controlled side experiment with $29^{\circ} \mathrm{C}$ set as the lower temperature limit, 6 nubbins of Porites cylindrica (kept in 1 aquarium) bleached when inoculated with stationary phase isolate T5, but only when the inoculation had taken place in the daytime. No signs of PUWS were observed in an un-inoculated control (Fig. 3). This response resembles bleaching of Pocillopora damicornis in the presence of Vibrio coralliilyticus that occurs only above $25^{\circ} \mathrm{C}$ (Ben-Haim \& Rosenberg 2002).

\section{Properties of the inoculum}

Appearance of characteristic ulcerative white spots (Fig. 1) depended also on the titer of the inoculum (Table 1). A titer of $10^{3}$ was sometimes insufficient to cause signs of PUWS, whereas $10^{4}$ cells $\mathrm{ml}^{-1}$ consistently caused ulcerative white spots within 2 to $4 \mathrm{wk}$. Higher cell densities of the inoculum caused immediate tissue lysis and death (tissue degradation) (Table 1). Tissue degradation had been observed mainly with isolate $\mathrm{T} 2$, which showed the highest specific activity of ectoprotease (3144 $\mathrm{g} \mathrm{h} \mathrm{h}^{-1} \mathrm{mg}^{-1}$ protein) in batch cultures of the 3 test strains. Protease activity of isolates T5 and T3 were 1726 and $309 \mu \mathrm{g} \mathrm{h}^{-1} \mathrm{mg}^{-1}$, respectively. Tissue degradation had previously been observed only on massive, but not branching, Porites species and was considered as a different disease (Raymundo et al. 2003). Existence of multiple signs of PUWS would be unprecedented notwithstanding a description of coalescing and spreading white spots among various Porites spp. (Raymundo et al. 2003). Field observations by Raymundo et al. (2005) included necrotic signs, but they did not relate these to PUWS.

It would be premature to assign the non-specific ectoprotease activity that is rather common among marine vibrios as a virulence factor in PUWS. Nevertheless, effects of the physiological status of the cells of Vibrio sp. T5 on infection results are striking (Table 1). Vibrio cells undergoing starvation survival (including stationary phase cells in batch cultures) increase their adhesive properties, and at the same time produce starvation survival proteins (Kjelleberg et al. 1983, Wang \& Leung 2000). In-depth molecular studies are needed to link PUWS and the properties of stationary phase cells of pathogenic Vibrio species to their virulence (Paul et al. 1991, Ben-Haim et al. 2003, McDougald et al. 2003, Nielsen et al. 2006, Sussman et al. 2008).

\section{Koch's postulates}

Koch's postulates as applied to bacterial pathogens of corals have been summarized by Rosenberg (2004). In 1-step immersion trials containing healthy corals in 9 replicate aquaria at ambient temperature (ranging between 25.1 and $30.6^{\circ} \mathrm{C}$ ), $67 \%$ showed ulcerative white spots as described by Raymundo et al. (2003) (Fig. 1). Complete absence of these disease signs from control treatments with sterile seawater or heat-killed suspensions of isolate T5 also confirmed the suitability of these open-air testing systems.

Maximum infection rates of $67 \%$ are comparable with those reported for bacterial bleaching of Oculina patagonica infected with Vibrio shiloi (Kushmaro et al. 1997), lower than the $100 \%$ infection rate of Pocillopora damicornis with $V$. coralliilyticus (Ben-Haim et al. 2003), and exceeding the effectiveness of white pox infections of Acropora palmata by Serratia marscescens (Patterson et al. 2002).

Re-isolation of the infectious test strain Vibrio sp. T5 from newly infected Porites cylindrica was achieved at the relatively low frequency of 1 out of 16 colonies growing on TCBS agar. This result could perhaps be explained by a strong secondary bacterial colonization, and in particular by an increase of sucrose-fermenting putative vibrios that are possibly instrumental to recovery from PUWS (M. J. Pueblos unpubl. data).

\section{Taxonomic classification of PUWS causing isolate}

Vibrio isolate T5 as well as the other disease causing Vibrio isolates T2 and T3 shared 99\% similarity of their 16S rRNA gene sequence with $V$. parahaemolyticus AY303956 (Nishiguchi \& Nair 2003). Yet, a cladogram based on type strains of Vibrio spp. puts Vibrio isolate T5 into the neighborhood of $V$. natriegens and $V$. proteolyticus (Farmer \& Janda 2005; Fig. 3). Phylogenetic distinction between Vibrio species that is merely based on $16 \mathrm{~S}$ rRNA gene similarities is most probably insufficient and should be considered on a broader basis including, in particular, multilocus sequence analysis (Thompson et al. 2005). Furthermore, a phenotypic dichotomous key suggested by Noguerola \& Blanch (2008) revealed a discrepancy with basic features of Vibrio isolate T5, since it failed to recognize it as a sucrose-fermenting pathogenic vibrio that can be isolated on TCBS agar. Work on the 
taxonomic identification of this PUWS causing bacterium must therefore be continued before a species name can be suggested and assigned.

Acknowledgements. This investigation was made possible by a Center of Excellence grant to W.T.R. within a GEF/Worldbank supported Coral Reef Targeted Research (CRTR) program. Additional funds for equipment came from DAAD (German Academic Exchange Service). Authors thank A. Siringan, Natural Sciences Research Institute, University of the Philippines (UP) Diliman, for providing laboratory support for taxonomic analysis.

\section{LITERATURE CITED}

Albertson NH, Nystroem T, Kjelleberg S (1990) Exoprotease activities of two marine bacteria during starvation. Appl Environ Microbiol 56:218-223

Altschul SF, Gish W, Miller W, Lipman DJ (1990) Basic local alignment search tool. J Mol Biol 205:203-215

Banin E, Israely Y, Kushmaro A, Loya Y, Orr E, Rosenberg E (2000) Penetration of the coral bleaching bacteria Vibrio shiloi into Oculina patagonica. Appl Environ Microbiol 66:3031-3036

Ben-Haim Y, Rosenberg E (2002) A novel Vibrio sp. pathogen of the coral Pocillopora damicornis. Mar Biol 141:47-55

Ben-Haim Y, Thompson FL, Thompson CC, Cnockaert MC, Hoste B, Swings J, Rosenberg E (2003) Vibrio coralliitycus sp. nov., a temperature dependent pathogen of the coral Pocillopora damicornis. Int J Syst Evol Microbiol 53: 309-315

Bolinches J, Romalde JL, Toranzo AE (1988) Evaluation of selective media for isolation and enumeration of vibrios from estuarine waters. J Microbiol Methods 8:151-160

> Bruno DW, Griffiths J, Petrie J, Hastings TS (1998) Vibrio viscosus in farmed Atlantic salmon Salmo salar in Scotland: field and experimental observations. Dis Aquat Org 34: 161-166

> Cervino JM, Hayes RL, Polson PW, Polson SC, Goreau TJ, Martinez RJ, Smith GW (2004) Relationship of Vibrio species infection and elevated temperature to yellow blotch/ band disease in Caribbean corals. Appl Environ Microbiol 70:6855-6864

> Colwell RR (1996) Global climate and infectious disease: the cholera paradigm. Science 274:2025-2031

> Colwell RR, Kaper J, Joseph SW (1977) Vibrio cholerae, Vibrio parahaemolyticus, and other vibrios: occurrence and distribution in Chesapeake Bay. Science 198:394-396

Dizon RM, Edwards AJ, Gomez ED (2008) Comparison of three types of adhesives in attaching coral transplants to clam shell substrates. Aquat Conserv: Mar Freshw Ecosys 18:1140-1148

Farmer JJ, Janda JM (2005) Vibrionaceae. In: Brenner DJ, Krieg NR, Staley JT, Garrity GM (eds) Bergey's manual of systematic bacteriology, 2nd edn, Vol 2. Springer-Verlag, New York, NY, p 491-555

Garren M, Smriga S, Azam F (2008) Gradients of coastal fish farm effluents and their effect on coral reef microbes. Environ Microbiol 10:2299-2312

> Geffen Y, Rosenberg E (2005) Stress induced rapid release of antibacterials by scleractinian corals. Mar Biol 146: 931-935

Hall TA (1999) BioEdit: a user-friendly biological sequence alignment editor and analysis program for Windows 95/98/NT. Nucleic Acids Symp Ser 41:95-98
Harris JR (2007) Negative staining of thinly spread biological samples. In: Kuo J (ed) Electron microscopy: methods and protocols, 2nd edn. Humana Press, Totowa, NJ, p 107-142

> Harvell CD, Kim K, Burkholder JM, Colwell RR and others (1999) Emerging marine diseases - climate links and anthropogenic factors. Science 285:1505-1510

> Hoegh-Guldberg O (1999) Coral bleaching, climate change and the future of the world's coral reefs. Mar Freshw Res 50:839-866

Kaczmarsky LT (2006) Coral disease dynamics in the central Philippines. Dis Aquat Org 69:9-21

Kita-Tsukamoto K, Oyaizu H, Nanba K, Simidu U (1993) Phylogenetic relationships of marine bacteria of the family Vibrionaceae, determined on the basis of 16S rRNA sequences. Int J Syst Bacteriol 43:8-19

> Kjelleberg S, Humphrey BA, Marshall KC (1983) Initial phases of starvation and activity of bacteria at surfaces. Appl Environ Microbiol 46:978-984

Kushmaro A, Rosenberg E, Fine M, Loya Y (1997) Bleaching of the coral Oculina patagonica by Vibrio AK-1. Mar Ecol Prog Ser 147:159-165

- Kushmaro A, Rosenberg E, Fine M, Ben-Hain Y, Loya Y (1998) Effect of temperature on bleaching of the coral Oculina patagonica by Vibrio Ak-1. Mar Ecol Prog Ser 171:131-137

> Lacoste A, Jalabert F, Malham S, Cueff A and others (2001) A Vibrio splendidus strain is associated with summer mortality of juvenile oysters Crassostrea gigas in the Bay of Morlaix (North Brittany, France). Dis Aquat Org 46: 139-145

> McDougald D, Srinivasan S, Rice SA, Kjelleberg S (2003) Signal-mediated cross-talk regulates stress adaptation in Vibrio species. Microbiology 149:1923-1933

Morita RY (1999) Bacteria in oligotrophic environments: starvation-survival life style. Chapman \& Hall, New York, NY

Nielsen AT, Dolganov NA, Otto G, Miller MC, Yu CY, Schoolnik GK (2006) Rpos controls the Vibrio cholerae mucosal escape response. PLoS Biol 2:933-948

Nishiguchi MK, Nair VA (2003) Evolution of pathogenicity and symbioses in Vibrionaceae: a combined approach using molecules and physiology. Int J Syst Evol Microbiol 53:2019-2026

Noguerola I, Blanch AR (2008) Identification of Vibrio spp. with a set of dichotomous keys. J Appl Microbiol 105: 175-185

> Nystrom T, Olsson RM, Kjelleberg S (1992) Survival, stress resistance, and alterations in protein expression in the marine Vibrio sp. strain s14 during starvation for different individual nutrients. Appl Environ Microbiol 58:55-65

Oliver JD (2005) The viable but non-culturable state in bacteria. J Microbiol 43:93-100

Oliver JD, Nilsson L, Kjelleberg S (1991) Formation of nonculturable Vibrio vulnificus cells and its relationship to the starvation state. Appl Environ Microbiol 57:2640-2644

> Patterson KL, Porter JW, Ritchie KB, Polson SW and others (2002) The etiology of white pox, a lethal disease of the Caribbean elkhorn coral, Acropora palmata. Proc Natl Acad Sci USA 99:8725-8730

Paul JH, Frischer ME, Thurmond JM (1991) Gene transfer in marine water column and sediment microcosms by natural plasmid transformation. Appl Environ Microbiol 57: 1509-1515

Porter KG, Feig YS (1980) The use of DAPI for identifying and counting aquatic microflora. Limnol Oceanogr 25:943-948

> Raymundo LJ, Harvell CD, Reynolds TL (2003) Porites ulcerative white spot disease: description, prevalence and host range of a new coral disease affecting Indo-Pacific reefs. Dis Aquat Org 56:95-104 
Raymundo LJ, Rosell KB, Reboton CT, Kaczmarsky L (2005) Coral diseases on Philippine reefs: genus Porites is a dominant host. Dis Aquat Org 64:181-191

Reichardt W (1988) Measurement of enzymatic solubilization of P.O.M. in marine sediments using dye release techniques. Arch Hydrobiol: Adv Limnol 31:353-363

Reichardt W, McGlone MLSD, Jacinto GS (2007) Organic pollution and its impact on the microbiology of coastal marine environments: a Philippine perspective. Asian J Water Environ Pollut 4:1-9

Rinderknecht H, Geokas MC, Silverman P, Haverback BJ (1968) A new ultrasensitive method for the determination of proteolytic activity. Clin Chim Acta 21:197-203

Robertson PAW, Calderon J, Carrera L, Stark JR, Zherdmant M, Austin B (1998) Experimental Vibrio harveyi infections in Penaeus vannamei larvae. Dis Aquat Org 32:151-155

Rosenberg E (2004) The bacterial hypothesis of coral bleaching. In: Rosenberg E, Loya Y (eds) Coral health and disease. Springer, Berlin

Rosenberg E, Koren O, Reshef L, Efrony R, Zilber-Rosenberg

Editorial responsibility: Garriet Smith,

Aiken, South Carolina, USA
I (2007) The role of microorganisms in coral health, disease and evolution. Nat Rev Microbiol 5:355-361

Roszak DB, Colwell RR (1987) Survival strategies of bacteria in natural environment. Microbiol Rev 51:365-379

Sambrook J, Fritsch EF, Maniatis T (1989) Molecular cloning: a laboratory manual, 2nd edn. Cold Spring Harbor Laboratory Press, Cold Spring Harbor, NY

Smith GW, Weil E (2004) Aspergillosis of gorgonians. In: Rosenberg E, Loya Y (eds) Coral health and disease. Springer, Berlin, p 279-288

Sussman M, Willis B, Victor S, Bourne DG (2008) Coral pathogens identified for white syndrome (WS) epizootics in the Indo-Pacific. PLoS One 3:e2393, doi:10.1371/ journal. pone.0002393

Thompson FL, Gevers D, Thompson CC, Dawyndt P and others (2005) Phylogeny and molecular identification of vibrios on the basis of multilocus sequence analysis. Appl Environ Microbiol 71:5107-5115

Wang XH, Leung KY (2000) Biochemical characterization of different types of adherence of Vibrio species to fish epithelial cells. Microbiology 146:989-998

Submitted: July 21, 2009; Accepted: March 10, 2010

Proofs received from author(s): June 2, 2010 